This item was submitted to Loughborough's Research Repository by the author.

Items in Figshare are protected by copyright, with all rights reserved, unless otherwise indicated.

\title{
Managing knowledge boundaries for open innovation - lessons from the automotive industry
}

PLEASE CITE THE PUBLISHED VERSION

https://doi.org/10.1108/IJOPM-06-2015-0337

\section{PUBLISHER}

(C) Emerald

\section{VERSION}

AM (Accepted Manuscript)

\section{PUBLISHER STATEMENT}

This paper was accepted for publication in the journal International Journal of Operations \& Production Management and the definitive published version is available at https://doi.org/10.1108/IJOPM-06-2015-0337.

\section{LICENCE}

CC BY-NC-ND 4.0

\section{REPOSITORY RECORD}

Wilhelm, M., and Wilfred Dolfsma. 2019. "Managing Knowledge Boundaries for Open Innovation - Lessons from the Automotive Industry". figshare. https://hdl.handle.net/2134/24833. 


\section{Managing Knowledge Boundaries for Open Innovation - Lessons from the Automotive Industry}

Purpose: The shifting locus of innovations from the firm to the supply chain level in the automotive industry has led to an advanced integration of suppliers in New Product Development (NPD). The rising need to innovate and obtain knowledge from more distant knowledge sources calls for new innovation strategies and calls for a better integration of other external actors who lie outside the traditional automotive supply chain. Such an open innovation strategy challenges organizational boundaries both on the firm and supply chain levels, yet our understanding of the functioning of such boundaries and how they can be managed to allow for purposive knowledge flows is limited.

Design/Methodology/Approach: In a longitudinal case study we trace the development of the first open innovation network in the German automotive industry over a period of 5 years based on (1) archival data, (2) semi-structured interviews, and (3) field observations.

Findings: While the automotive industry is advanced in collaborating with suppliers for innovation, routines for assessing and integrating ideas from sources outside the supply chain are still underdeveloped. We show which knowledge boundaries currently exist which pose obstacles for open innovation initiatives in this industry and how they could be mediated through the involvement of gatekeepers.

Originality/Value: We challenge and clarify the notion of the 'permeability of organizational boundaries' in the Open Innovation literature and investigate the role of gatekeepers for open innovation. As a mature industry, the automotive industry offers an excellent setting for this research. potential of applying an open innovation strategy in the automotive industry which has been a less investigated context for this strategy.

Keywords: Automotive Industry, Open Innovation, Knowledge Boundaries, Case study 


\section{Introduction}

Firms that pursue an open innovation strategy tend to achieve higher innovative performance (Laursen and Salter, 2006; Parida et al. 2012). Central to open innovation is the emphasis on a search for ideas and knowledge from external actors, which are brought into the firm and integrated into internal innovation processes (Vanhaverbeke, 2006). There is an unchallenged assumption in the open innovation literature that organizational boundaries (including firm, supply chain, and industry boundaries), become “porous” (Laursen and Salter, 2006) or even “fade” (Dittrich and Duysters, 2007) simply as a result of adopting this strategy. This raises questions of what organizational boundaries exactly are and how they can be "opened up" so that valuable knowledge from the outside can be identified and integrated.

Despite its centrality in the open innovation literature, the assumption of permeable boundaries is taken-for-granted and yet remains ill understood. In order to elucidate this theoretically and managerially relevant issue, we distinguish between two kinds of organizational boundaries, i.e., boundaries of activities, on the one hand, and boundaries of knowledge, on the other. "What firms make and what they know" (Brusoni et al., 2001: 600) can deviate, however, and a firm's knowledge boundaries often extend beyond boundaries of activities in production and other functions. How firms open up their boundaries of activities, by outsourcing part of production to external parties such as suppliers, competitors, and service firms, for example, is a well-understood phenomenon. The opening of knowledge boundaries is less understood, however, but deserves further investigation as the integration of knowledge that stems from external partners often proves to be difficult, particularly when the 
knowledge differs from existing knowledge domains of the firm (Piezunka \& Dahlander, 2015).

The process of opening knowledge boundaries could be particularly challenging for firms from mature and asset-intensive industries like automotive that have been shown to be more rigid in changing their internal innovation processes (Chiaroni et. al., 2011). Given the increasing range of automotive innovation - combining knowledge from several scientific disciplines such as chemistry (e.g. batteries), materials science (e.g. lightweight materials), and consumer electronics (e.g. infotainment) - it is becoming exceedingly difficult and costly for carmakers to "go deep” across all technologies_cf. Coronado Mondragon \& Miller 2006; Kamp \& Bevis 2012). The pressure to innovate and integrate new functionalities in the vehicle has increased carmakers' efforts to obtain innovations from outside their traditional firm and supply chain boundaries and embed themselves in more or less "loosely coupled networks of different actors” (Laursen and Salter, 2006). Carmakers are increasingly facing the need to not only build relationships with traditional automotive systems or parts suppliers (Karlsson \& Sköld 2013) - which are usually well integrated in their New Product Development (NPD) processes (Ragatz et al., 1997; Handfield et al., 1999; Cousins et al., 2011; Wong et al., 2013) - but also with other external actors such as private inventors, engineering firms and other service providers, research institutes, and competitors to provide them with new knowledge for innovations.

In order to answer the question - "How do firms manage organizational knowledge boundaries for open innovation,” we studied a major open innovation initiative that was founded in 2006 by major car manufacturers based in Germany. The insights from our longitudinal case study offers two contributions: First, the paper discusses for the first time in 
the context of the burgeoning open innovation literature how the 'permeability of organizational boundaries' can actually be understood and managed. In this context, we highlight the role of gatekeepers that perform a mediating role in increasing the permeability of knowledge boundaries. Second, we provide empirical insights from the hierarchically structured automotive industry, a type of industry where open innovation has been less studiedwhere we expect knowledge boundaries to be particularly rigid and the need for the Open Innovation literature to better understand the way in which organizational knowledge boundaries work is much more evident than in other industries. We show that while this industry is advanced in collaborating with automotive part-suppliers for innovation, it did not master the challenge of assessing and integrating ideas from sources outside the traditional supply chain, yet.

\section{Theoretical Background}

\subsection{Open Innovation in the automotive industry}

Open innovation is when a firm either actively seeks to obtain knowledge developed by other parties in order to incorporate it in its own innovation efforts, or provides knowledge it has developed itself to others for further development (West and Bogers, 2013). Inbound open innovation is when a firm enriches its own knowledge base by accessing external knowledge (e.g., through technology in-licensing or acquisition) (Chesbrough, 2003; Gassmann and Enkel, 2006). Commercializing innovations is often referred to as outbound open innovation when existing knowledge of the firm can be exploited outside firm boundaries by licensing IP or cross industry innovation (West and Bogers, 2013). As for many studies we focus on the 
more prevalent inbound open innovation, as it is also more dominant in practice (West et al., 2014).

The automotive industry has long been characterized as a scale-intensive industry where the majority of innovations are created by $R \& D$ departments of a few large firms (Pavitt, 1984). Growing demand from consumers for lighter and fuel-efficient cars with reduced emissions, more active and passive safety features, driving assistance and infotainment equipment (BCG, 2014) make creating and financing all innovations internally less viable. As a result, the prevailing mindset in the automotive industry is changing, as actors increasingly recognize "that not all ideas and innovations must be started by their own capacities” (Ili et al. 2010: 249).

Carmakers have reacted to these trends by intensifying collaboration with their first tier suppliers with the aim to develop new products and technologies (Helper and Sako, 2010; Clark and Fujimoto, 1991). More activities are either fully or partially carried out by established first tier suppliers such as Denso, Bosch and Valeo, and their importance in product development is expected to increase (BCG, 2014). The integration of suppliers in new product development is particularly critical in fields that lie outside traditional technological domains. Suppliers can be a primary source of product and process innovation in bringing environmental improvements to the plant (Geffen and Rothenberg, 2000) and play a critical role in Electric Vehicle development and assembly, as these require special capabilities (Ciravegna et al., 2013). There is, thus, a common understanding in the literature that buyersupplier cooperation is crucial for new product development processes of carmakers and herald the transition to open innovation strategies (Schuster \& Brem, 2015). 
Whereas the automotive industry can be considered advanced in managing boundaries with automotive parts suppliers, experience with integrating other external actors outside the industry is at a very nascent stage. This might be problematic as functional innovations increasingly require the integration of knowledge from distant domains that established suppliers do not offer, such as knowledge about psychophysiology (e.g. monitoring driver's fatigue) or specific information technology applications. Integrating outside-industry knowledge poses particular challenges, however. In their study of three cases in the automotive industry on the use of open innovation, Lazzarotti et al. (2013) found knowledge stemming from universities was often considered "far from the market". Even in those cases where a carmaker did manage to set up a successful collaboration with an outside industry innovator, the innovator would seldomly transition from a technology supplier to a component supplier with production responsibilities for series.

\subsection{The role of the gatekeepers for overcoming knowledge boundaries}

Open innovation often involves soliciting ideas from external contributors, which can be facilitated through the use of ICT. It constitutes a form of distant search, since firms will usually try to tap into knowledge that does not reside within their own boundaries (Piezunka and Dahlander, 2015). Obtaining innovations from outside implies, however, that boundaries between an organization and its environment are permeable for external knowledge flows. The permeability of boundaries is an underlying core assumption in the literature on open innovation, where once an organization decides to follow an open innovation strategy, a “purposive flow of knowledge” from outside takes place (Chesbrough, 2006: p. 1). Gassmann and Enkel (2004: p. 1) write, for example, that open innovation "transforms a company's 
solid boundaries into a semi-permeable membrane that enables innovation to move more easily between the external environment and the company's internal innovation process". Laursen and Salter (2006: p. 132) state that open innovation "redefines the boundary between the firm and its surrounding environment, making the firm more porous and embedded in loosely coupled networks of different actors”. Dittrich and Duysters (2007) even speak of firm boundaries "fading away" as firms move to networking partnerships for innovation. Yet, we know little about the nature of organizational boundaries and whether their permeability can indeed be purposefully influenced.

In this study we are particularly interested in the process of managing boundaries of knowledge that occurs when firms engage in open innovation activities. In order to gain a better understanding about the functioning of knowledge boundaries we build on the framework of Carlile (2002, 2004) who distinguishes between three types of knowledge boundaries that represent different degrees of difficulty in sharing knowledge: (1) Information processing boundaries that establish a relatively shared and stable syntax. Only when sender and receiver have a shared syntax can they (start to) recognize knowledge as relevant and potentially valuable, and proceed to exchange it. (2) Interpretative boundaries emphasize the importance of a common meaning of the knowledge shared among actors that come from different domains (such as different functions in product development). Even when a common syntax is present interpretative differences of the same word or object can emerge between members of different domains. (3) Pragmatic or political boundaries are the most difficult to overcome and exist because actors' different interests impede knowledge-sharing or because actors may simply not be aware of others in the organization being in need of certain knowledge. 
When there is a lack of common knowledge to assess outside knowledge, problems of sharing knowledge across boundaries are to be expected. Such problems are particularly acute the more distant and novel the knowledge is. Actors will then ignore "what is novel as something that is already known or discard what is novel as irrelevant” (Carlile, 2004: 557). In this context, gatekeepers have been found to play a critical role (Macdonald \& Williams, 1993) and there is a need to re-examine this role in light of the recent interest in open innovation that advocates the importance of networking beyond organizational boundaries (Whelan et al., 2010; Gemünden et al., 2007). Gatekeeping is more than a mere networking activity, however, it requires "translating between two systems" (Allen et al. 1979, p. 703). Whelan et al (2010) summarize three main tasks of gatekeepers, external knowledge acquisition, external knowledge translation, and internal knowledge dissemination. Gatekeepers - such as innovation managers in our case - scan the outside world for emerging technological developments relevant to the work of their R\&D and Technical Development departments. They subsequently translate this external knowledge into terms that are meaningful and useful to their more locally oriented colleagues. This translation function has been highlighted as the most important role of the gatekeeper (Allen, 1977) and does not only imply the framing of elements of one community's world view in terms of the world view of another community but also implies evaluating and explaining the relevance and significance of translations to the recipient's practice (Pawlowski \& Robey; 2004). Finally, gatekeepers disseminate external knowledge to targeted work colleagues whom they know would be able to use the information they have acquired (Macdonald \& Williams, 1994).

In summation, two related research areas inform our investigation. The literature on organizational knowledge boundaries sensitizes us to the structural conditions that influence the success of open innovation strategies in the automotive industry and beyond. The 
literature on gatekeepers provides us with an understanding of the potential mediating mechanism that would be useful for overcoming those structural conditions in the form of knowledge boundaries. In the context of our case of open innovation in the automotive industry, this gatekeeper role was performed by the carmakers’ innovation managers.

\section{Methodology}

Case studies are particularly strong for studying abstract concepts that are not directly observable, such as the concept of knowledge boundaries in this study. Empirically capturing knowledge boundaries is challenging and requires studying the context of the phenomenon as well as directly interacting with actors who create it (see also Carlile, 2002; 2004). Our ontological stance is that such boundaries only exist because of their construction through powerful actors who shape and reproduce such boundaries through their (discursive and practical) actions (Giddens, 1984). As such we follow an interpretive stance, and see phenomena such as knowledge transfer across organizational boundaries as socially constructed rather than as objective characteristics with universal application. Like all qualitative research, interpretative studies seek to reveal complexities, nuances, and details that are commonly omitted in quantitative studies.

We follow abductive reasoning where a general theory is sought to be reconciled with the observation in a balanced manner. In case study research, abductive reasoning involves modifying the logic of the general theory in order to reconcile it with contextual idiosyncrasies (Ketokivi \& Choi, 2014). If the observation deviates from the theory (i.e., the 'interpretative rule') the formulation of a new interpretative rule is desirable (Alvesson \& Kärreman, 2007). This type of reasoning is in fact one of the primary reasoning tools in 
scientific inquiry (Mantere \& Ketokivi, 2013) and differs from a purely inductive reasoning where an emergent theory is iterated with empirical data for the sake of theory-generation (see Eisenhardt, 1989).

The sampling of cases should be based on theoretical reasons, such as the revelation of an unusual phenomenon (Eisenhardt and Graebner, 2007: 279). We selected a unique case of an open innovation initiative in the German automotive industry that is embedded in a wider, project-based network, the "Automotive Innovation Network" (AIN). With over 60 official member firms (and a much larger number of companies active in the different projects and initiatives) the AIN has a large coverage of the German automotive industry with manufacturers like Porsche, BMW, and Daimler being active, as well as their first-tier suppliers, engineering service firms, consultants, and research institutes. The AIN has a more informal character and differs from consortia like SEMATECH in the U.S semiconductor industry (e.g. Spencer and Grindley, 1993; Browning et al., 1995), however, as it did not pursue an overall joint aim (e.g. develop semiconductor manufacturing technology), it was not financially subsidized by the government or the member firms, and there was no formal leadership.

\subsection{Data collection}

Our involvement with the open innovation initiative began in late-2006 and extended over five years. We used three main data sources: (1) archival data, (2) semi-structured interviews, and (3) field observations. We collected all relevant information from key members of the initiative and their interactions, and attended the specific project meetings and the AIN's annual two-day automobile summit. 
(1) Archival data. We were granted access to the complete email correspondence of one of the core members of the open innovation initiative, an innovation manager from one of the car manufacturers (coded as CAR4). The data contained over 1,500 emails with other members. These emails included recipients' lists and, in most cases, the whole conversation history as well as attachments such as meeting minutes, strategy papers, and presentations. We complemented this data by a comprehensive analysis of additional documents that were provided to us by the network manager and other network members.

(2) Interviews. We conducted telephone interviews with key actors of the open innovation initiative at two stages. In case of the five carmaker representatives that we interviewed this would be the innovation manager. All interviewed innovation managers have an engineering background but rather than being specialist in one field, they possess knowledge of a broad set of fields. All but one of them had a middle management position and more than 5 years of affiliation with the respective company, fitting the typical profile for a gatekeeper (Whelan et al., 2010). Additional interviews with innovation managers of two carmakers were conducted in 2016 to clarify some final questions that evolved during the revision process of this paper. Table 1 provides information about the interviews with core actors. A semi-structured instrument guided the interviews, ensuring that all topics of interest were covered. The interview protocol can be obtained from the authors on request. Depending on the background and position of a particular interviewee in the network we asked for the evolution of the open innovation initiative over time, open innovation practices, the involvement of particular actors in projects, and perceived outcomes.

[Insert Table 1 about here] 
A further 24 interviews, conducted between 2009 and 2011, with members from other working groups of the AIN as well as with innovation experts from consultancy companies, industry associations and regional development initiatives, and managers from other networks in the automotive industry provided important background information. The interviews typically lasted 60 minutes, and were taped and transcribed afterwards. Informal talks with experts, as well as with key informants from the open innovation group helped us to increase the validity of our data.

(3) Field observations. From the initial stage of the founding of AIN we were included in the general mailing list and received invitations for all meetings. Meetings attended (for an overview see Table 2) were documented by our team and field notes were written-up within 24 hours of the meetings.

\section{[Insert Table 2 about here]}

\subsection{Data Analysis}

When following a data analysis approach that can best be described as the disciplined iteration between general theory and the empirical data (Ketokivi \& Choi, 2014). We started open coding of the interviews by labeling key words, (sub)sentences, or paragraphs with codes and grouped them into internally consistent categories, in a largely inductive manner. Often we used a word or short phrase taken from the data as a code (in-vivo). This step was followed by axial coding to generate more abstract codes, delete and merge codes. During this stage, we started to connect our open codes to established constructs from our theoretical framework, such as the establishment of a shared syntax, diverging meanings, and the notinvented-here syndrome, in line with our aim of theory extension. Axial coding allowed us to 
root our data analysis in theory and helped to refine our concepts, leading to better reliability of the data. Table 3 provides insights into how the different coding categories were developed. The coding was done separately by both authors. Deviating interpretations, unclear codes, and ambiguities were discussed in several rounds and, as a result of these discussions, a high degree of consensus, could be achieved. In order to further validate our interpretations, we presented and discussed our findings with the members of the open innovation working group at two different points of time (2008 and 2012).

\section{[Insert Table 3 about here]}

Our methods also permitted some within-method and between-methods triangulation. We could compare the data obtained from interviews with the data available from documents and our observations. This way we could check for any inconsistencies that we could clarify with our interview partners in the last round of interviews in 2011.

\section{Managing Knowledge Boundaries for Open Innovation}

The open innovation group within the AIN was founded out of the growing recognition of carmakers that new technological impulses are less likely to stem from the traditional boundaries of the automotive supply chain:

"If the innovation is from our suppliers, I will get it anyway at some point. I have yearly meetings with` Bosch, Siemens and so on. (...). They don’t need to tell me here what is new because long before it becomes public they have already told me.” (meeting minutes, Innovation Manager CAR3)

As a consequence, the innovation competition they set up was thus mainly targeting small and medium sized companies that were believed to be more promising sources of novel innovative ideas and technologies than the well-known automotive parts suppliers. In 
particular, start-ups, entrepreneurs, and the "ingenious amateur inventor" who was “somewhere out there” was much trumpeted.

\subsection{Managing information processing boundaries}

One of the obstacles for open innovation in the automotive industry was that information processing boundaries were not sufficiently permeable for ideas from small inventors. Particular challenges that private inventors and start-ups were facing was that they were struggling to find the right contact person within the carmaker's organization, as a projectbased working style in the Technical Development function often led to a strong thematic focus.

Moreover, another information processing barrier was that communication channels only existed between carmakers and established suppliers and identifying the right contact person within the Technical Development function that could comprise up to 10,000 employees was difficult for outside innovators. As a result, communication about what an outside innovator had to offer, on the one hand, and what a car manufacturer was in need of (now or in the future), on the other, was thus unlikely. Moreover, even if inventors managed to get in touch with the right department, they were often unable to present their ideas to the OEM in an attractive way:

\footnotetext{
"The problem is that a company like Bosch has thousands of engineers working in a very systematic, organized, and scientific manner on solutions for the future. (...) The situation is different in the case of small inventors because they don't have a clue what is happening at the OEM and what the OEM is really in need of - even if they have a good idea they can't validate it and present it in a manner to get the interest of the OEM. (...) If someone sends me a 40-pages patent description, I have to be willing to read through (it)." (interview, Innovation Manager CAR3)
} 
A major issue was that private inventors often missed the chance to file a patent for their idea, which often led to the unwillingness of the innovation manager to even read the idea description:

"There is a legal problem with innovations that are not patented, yet. If intellectual property of someone else ends up my desk and I am willing to take a closer look at it, I can never be sure if legal liabilities occur. ” (Interview, Innovation Manager CAR4)

Thus, the difficulty of accessing the right contact person in the Technical Development function, and the preference for innovations that were already tested and verified for series production, presented in an attractive format, made it difficult for external knowledge to permeate information processing boundaries.

In order to overcome this problem, the newly set-up innovation competition was targeting existing ideas that were used in industries such as medical, pharmaceutical, health, telecommunications, entertainment, aviation and aerospace. The competition officially started on January 25, 2007 with a broad search scope and related routines for members and submitters: anybody could submit a "product, solution or prototype that is already in use in other industries” that had "a substantial transfer potential for the automotive industry, or could create a substantial added value for the end customer, or could change the use of the vehicle (e.g. energy saving)" (AIN-website, 2007). Submitters were strongly encouraged to file for a patent or trademark to enable the open sharing of their ideas. In order to facilitate a readerfriendly presentation a standardized submission format was designed which required a short description of the innovation, its maturity level and previous use, a picture or drawing, and an explanation of potential automotive use, restricted to two-pages in total. A jury of 20 innovation experts with representatives from most major German OEMs, as well as from suppliers, other firms and institutions evaluated the 150 submissions in the first year. After 
some internal discussions, the jury agreed on using simple and general evaluation criteria (consumer value, breadth of applicability in the vehicle, maturity of the innovation in its current field of application, expected product life duration of the innovation, sustainability, Customer acceptance) instead of more specific ones to allow for more openness for radical and unconventional ideas.

No monetary incentives were given but the best 30 innovative ideas were presented to the public at an "Innovation Vernissage" at the annual automobile summit where AIN members and other representatives of the German automotive industry meet. Thus, the open competition with a standardized submission format, the need to file for a patent prior to submission, the use of general evaluation criteria, and the direct interaction opportunities with inventors at the event helped the innovation managers of the carmakers to identify promising ideas and follow-up on them after the competition. It can thus be said that innovation managers of the five carmakers which were active in the initial stage of the innovation competition performed their gatekeeping role in terms of information acquisition.

\subsection{Managing interpretative boundaries}

Even though gatekeepers were successful in helping to overcome information processing boundaries, interpretative boundaries persisted as private inventors and carmakers often used the same terminology but attached different meanings to them:

"Oftentimes inventors and carmakers speak different languages. This becomes clear looking at their choice of names and terms. Oftentimes they carry a different meaning at the customer organization!" (Meeting Minutes, Innovation Manager, CAR3)

An additional obstacle for knowledge-transfer across boundaries was that jurors - despite• their broad technical expertise - had difficulties evaluating each submission as they were not technically familiar with each innovation submitted. Some, such as the innovation manager 
from CAR4, actively asked firm-internal experts from different technical development departments for their assessments when they lacked technical competence, as the internal email correspondence revealed. This is an initial indication that some of the innovation managers did not have the necessary expertise to perform the translation function of the gatekeeping role themselves. The lack of a translation of external knowledge that was often passed on internally in "raw" form was particularly problematic as the innovation manager in question often found it hard to identify the right contact person. Often there was no fit between the internal functional organization and the technologies described in the submission. This made it even more questionable if external knowledge was meaningfully interpreted within the firm and the evaluation was actually performed well.

It can be expected that the other innovation managers encountered similar problems within their firms as the overall evaluation results of the jury were anything but consistent:

\footnotetext{
"Looking at the individual evaluations of the submissions I recognize a huge variance that might lead to the outcome that some of the ideas score lower in the overall rating. This variance might distort the actual potential of an idea.” (email from Innovation Manager CAR5)
}

Moreover, despite the official claim to search for new and "disruptive” ideas, the evaluations were clearly biased towards already established ideas, which obtained the highest scores. The equal ranking of all five items of the evaluation criteria enhanced this effect (see Table A1 in the Appendix):

\footnotetext{
"Concerning the process of the evaluation of submissions it is striking that the oldest ideas, that are already known and discussed in the automotive industry, get the highest scores. This is of little surprise but the question remains how we can filter out the more subtle ideas that can promise new ways of consumer satisfaction.” (meeting Minutes, Innovation Manager CAR1)
}

As most jurors experienced the inflow of diverse ideas in the first year of the competition as overwhelming, the carmakers decided to more strongly target new knowledge from within the 
automotive industry and formulate theme clusters. The new themes more conventionally represent the current innovation focus of the automotive industry, which are "health and wellness” (including ergonomics, driving assistance, registration of physiological values such as driver’s tiredness), “navigation and infotainment” (including precise navigations for accident prevention), and " $\mathrm{CO}_{2}$ reduction and lightweight construction.” The clustering in the call for submissions, however, caused specific problems.

\begin{abstract}
"In the first year, we were rather broadly looking for innovations from other industries. Then we got this colorful mix of innovations. But the jury just couldn't handle this diversity (...) This is why we came up with the theme clusters in the following years. But then we ended up in the automotive sector again! And it is of no use for us if an automotive supplier like SKF submits their idea because someone from my company is very likely to already know it!" (interview, Innovation Manager CAR3)
\end{abstract}

This problem was further enhanced in the following year when the carmakers decided to introduce an additional cluster on "efficient and flexible production," that led to an almost doubling of the number of submissions, but did not generate the type of knowledge that carmakers were actually looking for:

\footnotetext{
"The innovation competition did grow well but we did not really manage to find real ideas for better products. If someone has an idea for improving production processes then they are usually positioned in the industry already and have their contact person.” (email from Innovation Manager CAR4)
}

In fact, cluster 3 and 4 (“ $\mathrm{CO}_{2}$ reduction and lightweight construction" and "efficient and flexible production”) attracted the largest number of submissions. Thus, the introduction of clusters in the innovation competition was successful in raising the quantity, but less so in inviting the "right" type of submissions. It thus seems that interpretative boundaries were not overcome by the innovation managers who were not able to perform the "translation" task of their gatekeeper role. As a consequence, rather than seeking direct interaction with outside industry actors to establish a common meaning, carmakers redirected their search efforts back to the familiar knowledge domains of the automotive industry. 


\title{
4.4. Managing political boundaries
}

Political boundaries are the most persisting element of knowledge boundaries, which was also reflected in our case. The internal organization of the carmakers' Technical Development departments, with a high degree of specialization around traditional technological domains such as platform, chassis, drivetrain, electric did not facilitate the adaption of novel ideas:

\footnotetext{
"Most innovation themes are determined by our $\mathrm{R} \& \mathrm{D}$ departments. Through the innovation competition we sometimes deliver impulses into the company (...). However, it is hard to find a port for these topics in the company because the organizational structure of our product development does not cover them.” (interview with Innovation Manager, CAR4)
}

Oftentimes the Technical Development was working on their own, alternative technology and was not interested in the specific submission.

"One needs to understand that people in Technical Development are usually working in a channeled
way based on predefined technological roadmaps. They are working on a technical task in a highly
structured way, with clear milestones and targets. If something new comes along that is completely
off-track, things are always difficult. They have limited interest to deal with new subjects."
(interview, Innovation Manager CAR3)

Interviews with the other carmakers revealed a similar picture:

\begin{abstract}
"Whether an innovation is followed up or not is a top-level decision. But before this happens you need to convince an engineer who is willing to go to his boss and tells him that this is a great idea. Top level managers will often not be familiar with the technical details - their job is to make decisions, but you need to convince the engineers first.” (interview, Innovation Manager CAR1)
\end{abstract}

Thus even though all interviewed innovation managers were active in their gatekeeper role to disseminate promising ideas to their internal networks within Technical Development departments, it was hard to actually convince their colleagues to follow up on these ideas. One way to help stress the innovative potential of the new knowledge against their own Technical Development function was, however, the reference to the discussions the innovation managers of the carmakers had with each other: 
"If you can take this impulse to your own firm and discuss it with the department in charge to say: 'Look, this is a new trend; we should start investing here.' And if you can also state that this is a trend your competitors are also looking into, then you have a strong argument that this might really be a hot topic." (interview, Innovation Manager CAR5)

Despite their reference to competitors the innovation managers were not able to overcome political boundaries within their firms. After six subsequent years of conducting the innovation competition, with no innovation idea that actually materialized in a vehicle, the carmaker representatives in 2012 jointly decided to stop their engagement in the innovation competition.

\section{Discussion}

By setting up an open innovation competition with a broad search scope that targeted 'distant' knowledge sources outside the existing automotive supply chain, the members of the open innovation initiative set up by carmakers in Germany tried to reach into unfamiliar knowledge domains. Our study demonstrates the difficulties of integrating external actors outside the automobile supply chain and the distant knowledge that they bring into carmakers' innovation processes. The car manufacturers aimed to have a truly open innovation process (Ili et al., 2010), but found that unacknowledged boundaries to absorbing and using foreign knowledge can frustrate this objective. In this paper we provide more insight into how such knowledge boundaries function, but also into how gatekeepers such as the innovation managers of different carmakers active in the open innovation initiative straddle these organizational knowledge boundaries. We summarize our main findings with three working propositions that specify the different roles of gatekeepers when they (potentially) mediate between the structural conditions of knowledge boundaries, and the structural consequences in terms of an increased permeability of knowledge boundaries in an open innovation context. The rendering 
of structural conditions and action in a reciprocal relationship is based in a perspective which conceives of social structure and human agency as interdependent constructs (Giddens, 1984).

Our case study showed that information processing existed at the different carmakers' organizations as prior to the innovation competition, outside-industry actors often chose the 'wrong presentation format' when they submitted their ideas - often in a non-patented form and did not use the right terminology that was requested by the carmakers. We, thus, propose:

Proposition 1: When gatekeepers fulfill their external knowledge acquisition role, for example, by inviting only patented ideas, submitted in a standardized format, a common $\mathrm{cm}$ syntax between actors within and outside the organization is created and permeability of information processing boundaries increases.

While the innovation managers turned out to be successful in performing their knowledge acquisition tasks and establishing a common syntax, a common meaning still needs to be established between inside and outside industry actors. Our case showed, however, that innovation managers often had to involve colleagues from different departments to evaluate ideas submitted to the innovation competition as they lacked the ability to transfer external information into terms that "are meaningful and useful to their more locally oriented colleagues” (Tushman \& Katz, 1980: 47). Translation does not only imply the framing of elements of one community's world view in terms of the world view of another community, but also implies evaluating and explaining the relevance and significance of translations to the recipient's practice (Pawlowski \& Robey, 2004). Thus, we propose:

Proposition 2: Despite the presence of a common syntax, outside knowledge is not meaningfully interpreted when gatekeepers fail to fulfill their external knowledge translation role, resulting in the impermeability of interpretative boundaries. 
Because ideas that won in the innovation competition often remained untranslated, they were frequently rejected by Technical Development departments. If knowledge is not adequately translated and transformed, no shared interest between actors outside and inside the (carmaker's) organization will develop. We uncover an important cause of the notinvented-here syndrome which is a main obstacle to successful implementation of open innovation (cf. Chesbrough, 2003; West and Bogers, 2013). A not-invented-here mentality in an organization need, however, not be purely 'political,' but can be a guise for a translation problem. In retrospect, the fact that the only official representatives from the carmakers' side were innovation managers could have constituted a specific problem of the innovation competition, as innovation managers were lacking the necessary depth of technical expertise to adequately translate foreign knowledge for internal decision-makers. This might also explain why it was so hard for the innovation managers to overcome political boundaries, even though they tried to increase the external legitimacy of new technologies by referring to the discussions with other carmakers:

Proposition 3: Once interpretative boundaries remain intact, political boundaries are likely to remain impermeable too, even if gatekeepers managed to build up external legitimacy for new knowledge.

Building on the insights of our case, our study makes three main contributions: First, we challenge the vague, but largely taken for granted notion of 'permeable' organizational boundaries in the open innovation literature (Gassmann and Enkel, 2004; Laursen and Salter, 2006; Dittrich and Duysters, 2007) by introducing the concept of "knowledge boundaries" (Carlile 2002, 2004; Brusoni et al., 2011). Second, we show that such boundaries could potentially be managed through the involvement of gatekeepers (Whelan et al., 2010; 
Gemünden et al., 2007). More specifically, we offer a more nuanced understanding of gatekeepers in an open innovation setting and how the different roles they perform are linked to the permeability of knowledge boundaries. Even though gatekeepers are often mentioned in passing in the open innovation literature, the different roles they might play have not been investigated in a more systematic manner (see also Trott \& Hartmann, 2009), or have only been advocated in more practitioner-oriented outlets (Whelan et al., 2011). Third, our involvement with the first open innovation initiative in the German automotive industry offered a unique chance to study the idiosynerasies of thisthe particular challenges this industry contextis facing when transitioning to an open innovation context. Only fewEven though some cases of open innovation in the automotive industry have been studied so far (e.g. Chiaroni et. al., 2011; Lazzarotti et al., 2013) - most likely due to the scarcity of empirical evidence and access problemsmost studies have focused on the integration of traditional industry actors such as system suppliers or Full Service Vehicle suppliers (e.g. Karlsson and Sköld, 2013; Coronado Mondragon et al., 2006). To the best of our knowledge, the AIN constituted the biggest open innovation initiative involving not just one, but multiple major carmakers. In contrast to previous findings in other industries that highlight the "notinvented-here" syndrome (i.e., political boundaries) as the main obstacle to open innovation (e.g., Laursen and Salter, 2006; West and Bogers, 2013; Chesbrough and Crowther, 2006), we found that it is particularly knowledge interpretation boundaries that are specifically hard to manage in this industry context. Interpretation boundaries result from the high degree of knowledge specialization that go in line with detailed specifications, and lengthy development eycles for automotive. ThusHowever, while the automotive industry can be considered advanced with respect to integrating knowledge from external suppliers (Ragatz et al., 1997; Handfield et al., 1999; Cousins et al., 2011; Wong et al., 2013), the very same practices for 
managing knowledge boundaries with suppliers make it difficult to change the industry's innovation model from a centralized and hierarchical one where large OEMs and their major suppliers collaborate, to a more decentralized one where OEMs serve as integrators that collaborate with large and small suppliers, private inventors, startups, engineering and design communities. In contrast to previous findings in other industries that highlight the "notinvented-here" syndrome (i.e., political boundaries) as the main obstacle to open innovation (e.g., Laursen and Salter, 2006; West and Bogers, 2013; Chesbrough and Crowther, 2006), we found that it is particularly knowledge interpretation boundaries that are specifically hard to manage in this context. Interpretation boundaries result from the high degree of knowledge specialization that go in line with detailed specifications, and lengthy development cycles for automotive. By this, also-onnecto more reent discussions on 'complex organizational

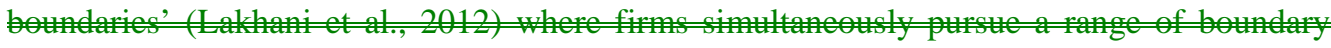
өptions that include "elosed" ventical integration, stategic allianees with key stppliexs, and “op" life complexity of organizational boundaries, and question the unrealistic assumption of boundaries becoming equally 'permeable' to all external actors._By this, we also connect to more recent discussions on ‘complex organizational boundaries’ (Lakhani et al., 2012) where firms simultaneously pursue a range of boundary options that include "closed" vertical integration, strategic alliances with key suppliers, and “open” boundaries and open innovation.

\section{Managerial Implications}


As our study highlights the difficulties and challenges of an open innovation strategy in general, and in the context of the automotive industry in particular, it also holds some valuable lessons for managers in this industry. First, it has been found that it is above all interpretative (and only resulting from that, political boundaries), which leads to problems of competently evaluating distant knowledge. One approach to overcome this shortcoming would be to create more interaction opportunities between carmaker representatives and inventors before or shortly after they submit their ideas. The lack of networking opportunities before the actual submission deadline could be seen as a general problem of this innovation competition, as it is also conceivable that inventors could benefit from active interaction with each other, as it is often good-practice in online web communities and idea competitions. Recent research on the supply side of the ideation process suggests that idea creators have an increased need for support in the idea elaboration stage. After an idea is generated it needs to be further refined and developed through constructive feedback and suggestions to help ideators identify ways to improve and expand their ideas (Perry-Smith \& Mannucci, 2015). Gatekeepers play again a crucial role here and can also help reduce emotional uncertainties that ideators might face (ibid.).

Moreover, involving technical expertise from Technical Development departments as more active members of the jury could also help to solve the translation problem. It has been argued that the gatekeeper role recently underwent a division of labor (Whelan et al., 2010) and separate specialists are needed to in tandem to perform these tasks. Thus, instead of involving single innovation managers as a representative from the carmaker's side, a team with more specialized, but complementary technical expertise could be assigned to participate in an open innovation initiative. As team members would also have direct, and ideally, non-overlapping 
reporting lines to internal decision-makers, this would also have a positive influence on political boundaries.

Finally, current partners with whom carmakers already collaborate, such as engineering services and suppliers, can serve as intermediaries possessing specific knowledge and experience that can make it easier for them to recognize, develop and apply foreign knowledge brought in through an open innovation competition. Suppliers, in particular, own component-specific knowledge, which might make it easier for them to recognize the application potential of ideas. Suppliers also possess the necessary experience and resources for testing and prototyping that private inventors and small entrepreneurs were lacking. Due to their long collaboration history, suppliers are also more familiar with the terminologies used at the carmaker's organization, alleviating the translation problem.

\section{Conclusion and Limitations}

For managers as well as for researchers our study suggests that the perception of distance between the knowledge domains of the players involved in knowledge exchange can be altered (to some degree). Allowing distant foreign knowledge to enter an organization and be successfully used requires that the outside knowledge is actively connected to what inside knowledge is available inside an organization. While we offer insights into how knowledge or interpretation boundaries work, and formulate suggestions on how they can be better managed in the open innovation process to increase their permeability, our study has some limitations: First, we were not able to "objectively" assess the quality of the submissions for the innovation process. Over the years, however, the number of ideas submitted increased 
substantially as the competition became better known. Carmakers in Germany have a strong reputation for quality and fairness in dealing with firms they collaborate with and outside parties would be highly motivated to participate (cf. Boudreau et al. 2011). A share of the ideas submitted through the competition will have had the potential to be further developed into useful contributions for carmakers. The likelihood that potentially valuable knowledge was actually not recognized is non-negligible.

This sheds light on another, related limitation that we were not able to collect data on the supply side of the innovation competition and conduct interviews with the inventors themselves - a limitation we acknowledge explicitly, but one that is related to the focus of our study. This would have offered a more complete picture in terms of how inventors could have been better supported in the ideation process (e.g. Perry-Smith \& Mannucci, 2015) in order to reduce knowledge boundaries also from the supply side. -

Furthermore, despite the excellent access we had to all major carmakers who were involved in this initiative and the necessary documents, collecting in-depth data for each of the participating firms' internal innovation processes was not feasible. A more systematic investigation of routines for searching and evaluating novel knowledge that are already in place in the firm, and how they changed, disappeared, or persisted when a new open innovation strategy is introduced constitutes a compelling avenue for further research. A better insight into firm-internal processes would have also provided us with a more nuanced understanding of political boundaries. This also opens the ground for further studies that explore how internal R\&D structures could best be aligned with the search for external knowledge (Ihl et al., 2012) to increase the success of open innovation strategies. 


\section{References}

Allen, T. J. (1977). Managing the flow of technology, Cambridge, MA: The MIT Press, 1984.

Alvesson, M., \& Kärreman, D. (2007). "Constructing mystery: Empirical matters in theory development”, Academy of management review, 32(4), 1265-1281.

BCG (2014), Automotive Value Creators Report 2014: A Comeback in the Making. https://www.bcgperspectives.com/content/articles/automotive_value_creation_strategy_2014_auto motive_value_creators_comeback_making/, accessed November 6 6 2015.

Boudreau, K. J., Lacetera, N., \& Lakhani, K. R. (2011). “Incentives and problem uncertainty in innovation contests: An empirical analysis”. Management Science, 57(5), 843-863.

Browning, L. D., Beyer, J. M., \& Shetler, J. C. (1995). "Building cooperation in a competitive industry: SEMATECH and the semiconductor industry”, Academy of Management Journal, 38(1), 113-151.

Brusoni, S., Prencipe, A., and Pavitt, K. (2001), “Knowledge specialization, organizational coupling, and the boundaries of the firm: why do firms know more than they make?”, Administrative science quarterly, 46(4), 597-621.

Carlile, P.R. (2002), “A pragmatic view of knowledge and boundaries: boundary objects in new product development”, Organization Science, 13: 422-455.

Carlile, P.R. (2004), “Transferring, Translating, and Transforming: An Integrative Framework for Managing Knowledge across Boundaries”, Organization Science 15(5), 555-568.

Chesbrough, H. (2003), Open innovation: the new imperative for creating and profiting from technology. Harvard Business School Press: Boston.

---- Chesbrough, H., \& Crowther, A. K. (2006). "Beyond high tech: early adopters of open innovation in other industries”, R\&D Management, 36(3), 229-236.

----, (2006), “Open innovation: A new paradigm for understanding industrial innovation”, in Chesbrough, H., Vanhaverbeke, W. and West, J. (ed.). Open innovation: researching a new paradigm. Oxford University Press: Oxford, pp. 1

Chiaroni, D., Chiesa, V. and Frattini, F. (2011). “The Open Innovation Journey: How firms dynamically implement the emerging innovation management paradigm”, Technovation, 31(1), 3443.

Ciravegna, L., Romano, P., and Pilkington, A. (2013). "Outsourcing practices in automotive supply networks: an exploratory study of full service vehicle suppliers”. International Journal of Production Research, 51(8), 2478-2490.

Clark, K. B., and Fujimoto, T. (1991). Product development. World Auto Industry: Strategy, Organization and Performance, Harvard Business School Press, Boston.

Coronado Mondragon, C.E., Coronado Mondragon, A.E., and Miller, R, (2006), "Modularity, open architecture and innovation: an automotive perspective" International Journal of Automotive Technology and Management 6(3): $346-363$.

Cousins, P. D., Lawson, B., Petersen, K. J., and Handfield, R. B. (2011). "Breakthrough scanning, supplier knowledge exchange, and new product development performance”. Journal of Product Innovation Management, 28(6), 930-942.

Dahlander, L. and Gann, D.M. (2010). „How Open is Innovation?” Research Policy 39(6), 699-709. 
Danese, P., \& Filippini, R. (2010). "Modularity and the impact on new product development time performance: Investigating the moderating effects of supplier involvement and interfunctional integration”, International Journal of Operations \& Production Management, 30(11), 1191-1209.

Dittrich, K., and Duysters, G. (2007), "Networking as a means to strategy change: the case of open innovation in mobile telephony”, Journal of Product Innovation Management, 24(6), 510-521.

Eisenhardt, K. M. (1989). “Building theories from case study research”, Academy of Management Review, 14(4), 532-550.

Eisenhardt, K. M. and Graebner, M. E. (2007), “Theory building from cases: opportunities and challenges”, Academy of Management Journal, 50 (1), 25-32.

Gassmann, O., Enkel, E., and Chesbrough, H. (2010), “The future of open innovation”, $R \& D$ Management, 40(3), 213-221.

Gassmann, Oliver, and Ellen Enkel (2004), “Towards a theory of open innovation: three core process archetypes”, In R\&D Management Conference, vol. 6.

Geffen, C. A., and Rothenberg, S. (2000). "Suppliers and environmental innovation: the automotive paint process”. International Journal of Operations \& Production Management, 20(2), 166-186.

Gemünden, H. G., Salomo, S., \& Hölzle, K. (2007). "Role models for radical innovations in times of open innovation”. Creativity and innovation management, 16(4), 408-421.

Giddens, A. (1984). The constitution of society: Outline of the theory of structuration. University of California Press.

Handfield, R. B., Ragatz, G. L., Peterson, K., and Monczka, R. M. (1999). "Involving suppliers in new product development?” California Management Review, 42, 59-82.

Helper, S., and Sako, M. (2010). "Management innovation in supply chain: appreciating Chandler in the twenty-first century". Industrial and Corporate Change, 19(2), 399-429

Henkel, J., Schöberl, S., \& Alexy, O. (2014). "The emergence of openness: How and why firms adopt selective revealing in open innovation.” Research Policy, 43(5), 879-890.

Ihl, C., Piller, F. T., \& Wagner, P. (2012). “Organizing for open innovation: Aligning internal structure with external knowledge search”, Available at SSRN 2164766.

Ili, S., Albers, A., and Miller, S. (2010), “Open innovation in the automotive industry”, $R \& D$ Management, 40(3), 246-255.

Kamp, B., and Bevis K. (2012), "Knowledge transfer initiatives as a doorstep formula to open innovation”, International Journal of Automotive Technology and Management, 12(1): 22 - 54.

Karlsson, C \& Sköld, M. (2013), "Forms of innovation openness in global automotive groups”, International Journal of Automotive Technology and Management 13(1): 1 - 17.

Ketokivi, M., \& Choi, T. (2014). "Renaissance of case research as a scientific method”, Journal of Operations Management, 32(5), 232-240.

Lakhani, K., Lifshitz-Assaf, H., \& Tushman, M. (2012). “Open innovation and organizational boundaries: the impact of task decomposition and knowledge distribution on the locus of innovation”. Harvard Business School Technology \& Operations Mgt. Unit Working Paper, (1257), 12-057.

Lazzarotti, V., Manzini, R., Pellegrini, L., \& Pizzurno, E. (2013). “Open Innovation in the automotive industry: Why and How? Evidence from a multiple case study”, International Journal of Technology Intelligence and Planning, 9(1), 37-56. 
Laursen, K. and Salter, A. (2006), “Open for innovation: the role of openness in explaining innovation performance among U.K. manufacturing firms”, Strategic Management Journal, 27(2): 131-150.

Lockstroem, M., Schadel, J., Harrison, N., Moser, R., and Malhotra, M. K. (2010), “Antecedents to supplier integration in the automotive industry: a multiple-case study of foreign subsidiaries in China”, Journal of Operations Management, 28(3), 240-256.

Macdonald, S., \& Williams, C. (1993). "Beyond the boundary: an information perspective on the role of the gatekeeper in the organization”, Journal of Product Innovation Management, 10(5), 417427.

Mantere, S., \& Ketokivi, M. (2013). "Reasoning in organization science”, Academy of Management Review, 38(1), 70-89.

Parida, V., Westerberg, M., \& Frishammar, J. (2012). „Inbound open innovation activities in high-tech SMEs: the impact on innovation performance”, Journal of Small Business Management, 50(2), 283-309.

Pavitt, K. (1984), "Sectoral patterns of technical change: towards a taxonomy and a theory", Research Policy, 13(6), 343-373.

Pawlowski, S. D., \& Robey, D. (2004). "Bridging user organizations: Knowledge brokering and the work of information technology professionals”, MIS Quarterly, 645-672.

Perry-Smith, J., \& Mannucci, P. V. (2015). "From creativity to innovation: The social network drivers of the four phases of the idea journey”, Academy of Management Review, doi: 10.5465/amr.2014.0462.

Piezunka, H., and Dahlander, L. (2015), "Distant search, narrow attention: how crowding alters organization's filtering of suggestions in crowdsourcing”, Academy of Management Journal, 58(3): 856-880.

Ragatz, G. L., Handfield, R. B., and Scannell, T. V. (1997). "Success factors for integrating suppliers into new product development”. Journal of Product Innovation Management, 14(3), 190-202.

Sako, M. (2004). "Supplier development at Honda, Nissan and Toyota: comparative case studies of organizational capability enhancement”, Industrial and Corporate Change, 13(2), 281-308.

Schuster, G., \& Brem, A. (2015). "How to benefit from open innovation? An empirical investigation of open innovation, external partnerships and firm capabilities in the automotive industry", International Journal of Technology Management, 69(1), 54-76.

Spencer, W. J., \& Grindley, P. (1993). "SEMATECH after five years: high-technology consortia and US competitiveness.” California Management Review, 35(4), 9-32.

Trott, P., \& Hartmann, D. A. P. (2009). "Why 'open innovation' is old wine in new bottles”, International Journal of Innovation Management, 13(04), 715-736.

Tushman, M. L., \& Katz, R. (1980). „External communication and project performance: An investigation into the role of gatekeepers”, Management Science, 26(11), 1071-1085.

Vanhaverbeke, W. (2006), “The Inter-organizational context of open innovation”, in Chesbrough, H., Vanhaverbeke, W. and West, J. (ed.), Open innovation: researching a new paradigm. Oxford University Press: Oxford, pp. 205-219.

West, J., and Bogers, M. (2013), "Leveraging external sources of innovation: a review of research on open innovation”, Journal of Product Innovation Management, 31(4), 814-831.

West, J., Salter, A., Vanhaverbeke, W., and Chesbrough, H. (2014), “Open innovation: The next decade”, Research Policy, 43(5), 805-811. 
Whelan, E., Parise, S., De Valk, J., \& Aalbers, R. (2011).” Creating employee networks that deliver open innovation”, MIT Sloan Management Review, 53(1), 37.

Wong, C.W.Y., Wong. C.Y., Boon-itt, S (2013). “The combined effects of internal and external supply chain integration on product innovation”. International Journal of Production Economics 146 (2013) 566-574

\section{Tables}

\begin{tabular}{|c|c|c|c|c|c|c|}
\hline \multirow[t]{2}{*}{ Company } & \multirow{2}{*}{$\begin{array}{l}\text { Interview } \\
\text { partner }\end{array}$} & \multirow{2}{*}{$\begin{array}{l}\text { Interview partner's } \\
\text { hierarchical position }\end{array}$} & \multirow{2}{*}{$\begin{array}{l}\text { Years in } \\
\text { company }\end{array}$} & \multicolumn{3}{|c|}{ Year } \\
\hline & & & & 2009 & 2011 & 2016 \\
\hline CAR1 & $\begin{array}{l}\text { Innovation } \\
\text { Manager }\end{array}$ & $\begin{array}{l}\text { Head of “Innovation } \\
\text { Team” }\end{array}$ & $>20$ & $\mathrm{X}$ & $X$ & $\mathrm{X}$ \\
\hline CAR2 & $\begin{array}{l}\text { Innovation } \\
\text { Manager }\end{array}$ & \begin{tabular}{|l} 
Team leader \\
"Innovation \\
Management"
\end{tabular} & $>5$ & $\mathrm{X}$ & $\mathrm{X}$ & \\
\hline CAR3 & $\begin{array}{l}\text { Innovation } \\
\text { Manager }\end{array}$ & $\begin{array}{l}\text { Director “Research \& } \\
\text { Operations” (European } \\
\text { R\&D Center), }\end{array}$ & $>20$ & $\mathrm{X}$ & $\mathrm{X}$ & $\mathrm{X}$ \\
\hline CAR4 & $\begin{array}{l}\text { Innovation } \\
\text { Manager }\end{array}$ & $\begin{array}{l}\text { Senior Manager } \\
\text { "Advanced Technology } \\
\text { and Research” }\end{array}$ & $>10$ & $\mathrm{X}$ & $\mathrm{X}$ & \\
\hline CAR5 & $\begin{array}{l}\text { Innovation } \\
\text { Manager }\end{array}$ & $\begin{array}{l}\text { Team leader } \\
\text { “Technology Planning” }\end{array}$ & $>5$ & & $\mathrm{X}$ & \\
\hline
\end{tabular}

Table 1: Interviews with core jury members of the innovation competition

\begin{tabular}{|l|l|}
\hline Type of meeting & Meetings attended (\#) \\
\hline Kickoff-meeting (AIN) & 2007 \\
\hline Annual automobile summit & $2007,2008,2009,2010$ \\
\hline Project meeting (Open Innovation working group) & $2008(2)$ \\
\hline General network meeting (AIN) & $2008,2009,2010$ \\
\hline
\end{tabular}

Table 2: Meetings attended 


\begin{tabular}{|c|c|c|c|}
\hline $\begin{array}{l}\text { Managing } \\
\text { knowledge } \\
\text { boundaries }\end{array}$ & $\begin{array}{l}\text { Empirical } \\
\text { evidence }\end{array}$ & Interpretation & Representative quotes \\
\hline \multirow[t]{2}{*}{$\begin{array}{l}\text { Information } \\
\text { processing boundaries } \\
\text { Definition: Incidents } \\
\text { where respondents } \\
\text { describe the } \\
\text { uncontrolled inflow of } \\
\text { ideas and the lack of a } \\
\text { shared syntax between } \\
\text { inside and outside } \\
\text { industry actors, and } \\
\text { attempts to deal with } \\
\text { this. } \\
\text { Example codes: shared } \\
\text { syntax, standardized } \\
\text { presentation, } \\
\text { information overflow, } \\
\text { knowledge acquisition }\end{array}$} & $\begin{array}{l}\text { - Requirement to } \\
\text { present new ideas } \\
\text { as a prototype with } \\
\text { feasibility studies } \\
\text { and extensive } \\
\text { testing. } \\
\text { - "Unattractive" } \\
\text { presentation of } \\
\text { ideas, often only in } \\
\text { form of patent } \\
\text { description. }\end{array}$ & $\begin{array}{l}\text { Structural conditions } \\
\text { - Ideas from external } \\
\text { sources outside the } \\
\text { automotive supply } \\
\text { chain often had the } \\
\text { "wrong presentation } \\
\text { format" and the lack of } \\
\text { knowledge about the } \\
\text { needs of the carmakers. }\end{array}$ & $\begin{array}{l}\text { "Each week unsolicited ideas pile up on my } \\
\text { desk ....I am not saying that there could be no } \\
\text { idea of value among them but it would require } \\
\text { a lot of goodwill and effort to filter them out." } \\
\text { (interview with Innovation Manager, CAR1) } \\
\text { “(...) small inventors (...) don't have a clue } \\
\text { what is happening at the OEM and what the } \\
\text { OEM is really in need of - even if they have a } \\
\text { good idea they can't validate it and present it } \\
\text { in a manner to get the interest of the OEM. (...) } \\
\text { If someone sends me a } 40 \text {-pages patent } \\
\text { description, I have to be willing to read } \\
\text { through (it).” (interview with Innovation } \\
\text { Manager, CAR3) }\end{array}$ \\
\hline & $\begin{array}{l}\text { - Online } \\
\text { submission system } \\
\text { enables innovation } \\
\text { manager to access } \\
\text { wider pool of ideas. } \\
\text { - Prescription of a } \\
\text { standardized } \\
\text { submission format. } \\
\text { - Standardized and } \\
\text { general evaluation } \\
\text { criteria. }\end{array}$ & $\begin{array}{l}\text { Structural consequences } \\
\text { - The standardized } \\
\text { presentation format } \\
\text { helped to reduce } \\
\text { information processing } \\
\text { boundaries. }\end{array}$ & $\begin{array}{l}\text { "There as a clear presentation of the ideas on } \\
\text { which we could apply ranking system. This } \\
\text { allowed us to discuss the top } 70 \text { ideas one by } \\
\text { one and make sense of them." (interview with } \\
\text { Innovation Manager, CAR2) } \\
\text { "The standardized submissions format } \\
\text { definitely helped to get a quick and good } \\
\text { impression of the ideas. Sometimes I felt that } \\
\text { more descriptions would have been necessary } \\
\text { for me to be able to really evaluate an idea } \\
\text { though...." (email of a jury member) }\end{array}$ \\
\hline \multirow{2}{*}{$\begin{array}{l}\text { Interpretative } \\
\text { boundaries } \\
\text { Definition: Incidents } \\
\text { where respondents } \\
\text { emphasize the lack of a } \\
\text { common meaning of } \\
\text { the knowledge shared } \\
\text { among actors from } \\
\text { within and outside the } \\
\text { industry and attempts to } \\
\text { deal with this. } \\
\text { Example codes: } \\
\text { common/different } \\
\text { understanding, } \\
\text { 'exoticsm', translation, } \\
\text { familiar players }\end{array}$} & $\begin{array}{l}\text { - Inventors often } \\
\text { do not use the } \\
\text { "right" language } \\
\text { and terminology. }\end{array}$ & $\begin{array}{l}\text { Structural conditions } \\
\text { - Non-familiarity with } \\
\text { the right language } \\
\text { creates interpretative } \\
\text { boundaries between } \\
\text { inside and outside } \\
\text { industry actors. }\end{array}$ & $\begin{array}{l}\text { "Private inventors are often not familiar with } \\
\text { the terminology that we are using in our } \\
\text { company....Actually, they might be using the } \\
\text { same words but they have no idea that these } \\
\text { words are used differently here..." (meeting } \\
\text { minutes, Innovation Manager CAR2) } \\
\text { "Oftentimes inventors and carmakers speak } \\
\text { different languages. This becomes clear } \\
\text { looking at their choice of names and terms. } \\
\text { Oftentimes they carry a different meaning at } \\
\text { the customer organization!" (meeting minutes, } \\
\text { Innovation Manager CAR3) }\end{array}$ \\
\hline & $\begin{array}{l}\text { - Innovation } \\
\text { managers pass on } \\
\text { knowledge in 'raw } \\
\text { form' } \\
\text { - Use of predefined } \\
\text { clusters to reduce } \\
\text { interpretative } \\
\text { differences with } \\
\text { outside automotive } \\
\text { domains. }\end{array}$ & $\begin{array}{l}\text { Structural } \\
\text { consequences } \\
\text { - Outside knowledge is } \\
\text { not adequately } \\
\text { translated and } \\
\text { relevance for potential } \\
\text { users remains unclear. } \\
\text { - Clustering reduces } \\
\text { interpretation } \\
\text { boundaries but leads to } \\
\text { the inflow of less novel } \\
\text { knowledge. }\end{array}$ & $\begin{array}{l}\text { "My job requires that I have a broad technical } \\
\text { expertise. I don't know the in-depth details of } \\
\text { all technical innovations presented here and in } \\
\text { order to make a plausibility check I have to ask } \\
\text { my colleagues." (Interview with Innovation } \\
\text { Manager CAR5) } \\
\text { "My concern at the moment is that we are } \\
\text { getting less consumer related innovations but } \\
\text { production process related ones - see cluster } 1 \\
\text { and } 2 \text { compared to cluster } 3 \text { and } 4 \text {. The } \\
\text { principal question for me is, however, whether } \\
\text { we want to have a product or production }\end{array}$ \\
\hline
\end{tabular}




\begin{tabular}{|c|c|c|c|}
\hline & & & $\begin{array}{l}\text { innovation competition." (email from } \\
\text { Innovation Manager, CAR1) }\end{array}$ \\
\hline \multirow[t]{2}{*}{$\begin{array}{l}\text { Political boundaries } \\
\text { Definition: Incidents } \\
\text { where respondents } \\
\text { describe firm-internal } \\
\text { reasons for rejecting an } \\
\text { innovative idea from } \\
\text { outside and attempts to } \\
\text { deal with this. } \\
\text { Example codes: firm- } \\
\text { specific } \\
\text { strategies/technologies, } \\
\text { organizational } \\
\text { structure, knowledge } \\
\text { dissemination, 'right' } \\
\text { contact person, external } \\
\text { legitimacy }\end{array}$} & $\begin{array}{l}\text { - Organizational } \\
\text { structure of the } \\
\text { internal Technical } \\
\text { Development } \\
\text { departments makes } \\
\text { it difficult to find } \\
\text { the right recipient. } \\
\text { - Internal } \\
\text { Technical } \\
\text { Development } \\
\text { departments were } \\
\text { often working on } \\
\text { alternative } \\
\text { technologies. }\end{array}$ & $\begin{array}{l}\text { Structural conditions } \\
\text { - Highly specialized } \\
\text { departments that are } \\
\text { structured around } \\
\text { traditional automotive } \\
\text { technologies create } \\
\text { political boundaries. }\end{array}$ & $\begin{array}{l}\text { "The structure of the Technical Development } \\
\text { function is rather conventional which makes it } \\
\text { often hard for me to find the right port for a } \\
\text { winning idea." (interview, Innovation Manager } \\
\text { CAR5) } \\
\text { "All innovation decisions in our company are } \\
\text { made at the board level. So an engineer would } \\
\text { need to be really enthusiastic about an idea so } \\
\text { that he will go to his boss, and his boss with go } \\
\text { to his boss to say: 'This is a great idea, we } \\
\text { really need it!' So the idea must be incredibly } \\
\text { good to convince someone to follow this path." } \\
\text { (interview, Innovation manager CAR1) }\end{array}$ \\
\hline & $\begin{array}{l}\text { - Innovations } \\
\text { managers of } \\
\text { different carmakers } \\
\text { discuss novel } \\
\text { technologies to } \\
\text { reduce the } \\
\text { uncertainties and } \\
\text { can create external } \\
\text { legitimacy. }\end{array}$ & $\begin{array}{l}\text { Structural } \\
\text { consequences } \\
\text { - External legitimacy is } \\
\text { not sufficient to reduce } \\
\text { political boundaries. }\end{array}$ & $\begin{array}{l}\text { "We identify trends that matter for our core } \\
\text { business and we provide impulses for our } \\
\text { company. Based on our activities, I might } \\
\text { prepare a presentation for our board of } \\
\text { directors. And if I can refer to the discussion } \\
\text { we had at the Innovation roundtable I have a } \\
\text { much stronger case internally to say: Look this } \\
\text { could be interesting. The other carmakers are } \\
\text { also thinking about it." } \\
\text { (Innovation manager CAR1) } \\
\text { “...all the time we were always looking for the } \\
\text { ingenious amateur inventor from the Black } \\
\text { Forest. We know now: this amateur inventor } \\
\text { does not exist, at least not for the Automotive } \\
\text { industry." (interview, Innovation Manager } \\
\text { CAR1) }\end{array}$ \\
\hline
\end{tabular}

Table 3: Central coding categories and representative quotes 